\title{
TOPOGRAFIAS DA VIOLÊNCIA: NECROPODER E GOVERNAMENTALIDADE ESPACIAL EM SÃO PAULO ${ }^{1}$
}

\begin{abstract}
Jaime Amparo Alves ${ }^{2}$
Resumo: A partir da análise da oferta de leitos hospitalares, da violência policial e da distribuição desigual de mortes violentas no espaço urbano da cidade entre 2003 e 2008, o artigo sugere que há um padrão mórbido de governança espacial que elege determinadas geografias urbanas e determinados corpos como os alvos de controle e produção do medo e da violência. Os conceitos de necropoder e governamentalidade discutidos por Michael Foucault e Achille Mbembe, respectivamente, sustentam o argumento de que a distribuição desigual da morte no município se constitui em uma necro-política estatal de gestão do espaço urbano e controle da população, seja por omissão seja por cumplicidade com os padrões mórbidos de relações raciais no Brasil.
\end{abstract}

Palavras-chave: morbi-mortalidade, geografia urbana, violência, raça, necropolitica.

\section{TOPOGRAPHIES OF VIOLENCE: NECROPOWER, AND SPATIAL GOVERNMENTALITY IN SÃO PAULO}

Abstract: Based on analysis of the distribution of violent deaths in the urban space of the municipality of Sao Paulo between 2003 and 2008, the article suggests that there is a morbid patterns of spatial governance that elects specific urban geographies and specific bodies as the main target if control and production of fear. Based on Foucault's concepts of governmentality and Achilles Mbembe's concept of necropower, the work also suggests that the concentration of death in predominately black neighborhoods constitutes a statesponsored necropolitic. Such politic of death is expressed in the state omission and/or its complicity with the morbid patterns of racial relations in Brazil.

Keywords: morbid-mortality, urban geography, violence, race and necropolitics.

\section{INTRODUÇÃO}

Neste artigo, exploro os efeitos da simbiose espaço-raça na produção de territórios da violência e de oportunidades na cidade de São Paulo. O meu ponto de partida é o

\footnotetext{
${ }^{1}$ Agradeço a João Costa Vargas pelas reflexões a cerca da 'geografia da morte' em Sao Paulo, e a José Carlos Freire, Maria Aparecida das Graças, Fúlvia Rosemberg, Vera Rodrigues, bem como a/o parecerista anônimo/a pelos comentários em versão preliminar. Agradecimento especial aos parceiros da Uneafro-Brasil, firmes na luta por uma cidade justa. Este artigo aprofunda os argumentos apresentados de maneira preliminar em Alves, Jaime Amparo. "Necropolitica racial: a produção espacial da morte em São Paulo". Revista da ABPN. 1, n. 3-nov-fev, p. 89-114, 2010.

${ }^{2}$ Pesquisador do Centro de Estudos Africanos e Afro-Americanos/Departamento de Antropologia Social da Universidade do Texas, em Austin (EUA) - Email: amparoalves@gmail.com
}

DOI: 10.7154/RDG.2011.0022.0006 
reconhecimento da categoria "raça" como produção social importante na definição de quem vive e quem morre no espaço urbano da metrópole paulistana (VARGAS; ALVES 2009). Ao contrário de uma suposta harmonia no quadro das relações raciais no Brasil, como se quer fazer crer a literatura hegemônica sobre o assunto (MARCOS;MAGGIE 2007, KAMEL 2006, FRY 1995), conceituo raça como uma realidade socialmente construída que estrutura as relações sociais e define não apenas o acesso diferenciado à cidadania, mas também o direito à vida ${ }^{3}$.

Se "raça" em termos biológicos é uma ficção, o mesmo não se pode dizer das suas implicações materiais na vida das populações racializadas. Por si só, os padrões de violência homicida não apenas desafiam os entendimentos ambivalentes sobre raça segundo os quais o Brasil se difere dos Estados Unidos e da África do Sul - como também sugerem nesse contexto um "modelo antropofágico de relações étnico-raciais" (PAIXÃO, 2005, p.04) em que o corpo negro aparece como o locus privilegiado da violência. Os pesquisadores da violência urbana têm identificado não apenas uma "afinidade eletiva" entre punição e cor (ADORNO 1995, SILVA 1998), como também um "padrão da mortalidade juvenil" (WAISELFISZ 2011) que elege jovens negros urbanos como as principais vítimas dos assassinatos no país. Mais: se o assassinato de indivíduos em plena idade produtiva já expõe a tragédia programada do Brasil do futuro, o assassinato de negras e negros expõe também o exercício estatal de um necropoder racial pelo qual o Estado mata por deixar morrer ${ }^{4}$. Baseado na tríade lefebvriana, sugiro também que 'espaço urbano' e 'raça' - assim como idade, gênero e classe - são categorias importantes pelas quais o urbano é vivido, imaginado e percebido no contexto da violência letal. Finalmente, proponho entendermos a violência estatal - em suas multiplas faces - como uma categoria "necropolítica"(MBEMBE 2003) pela qual o Estado exerce o seu poder de soberania. Todavia, entendo como violência estatal não apenas as já banalizadas práticas policiais de extermínio e massacre nas favelas, mas também a cumplicidade e a

\footnotetext{
3 Neste sentido, as proposições a seguir se baseiam no conceito de racismo tal como proposto por Gilmore (2007, p.247): “a produção, extra-legal ou patrocinada pelo estado, de padrões diferenciados de vulnerabilidade à morte prematura".

4 Negros morrem mais e mais cedo do que os brancos. A taxa de homicídio juvenil, segundo os dados de 2008 , é proporcionalmente $103,4 \%$ maior entre os negros que brancos. Em estados como a Paraíba e Alagoas, a taxa de vitimização juvenil negra é de $1971,2 \%$ e $1304,0 \%$ respectivamente (WAISELFISZ, 2011, p. 62).
} 
displicência estatal com a violência homicida, a violência cotidiana expressa na segregação espacial, a negação sistemática dos direitos de cidadania, as mortes evitáveis nas filas dos hospitais públicos (BATISTA 2003, ROMIO 2009, FLAUZINA 2008, ALVES 2010).

Entender a violência como prática difusa e dissimulada pode ajudar a explicar como certos indivíduos e instituições incorporam o Estado em suas práticas, e como micro-formas de intervenção estatal - nas bases comunitárias de segurança, nas escolas, nas prisões, no ordenamento do espaço urbano - reproduzem e sustentam formas sofisticadas de controle social ${ }^{5}$. Finalmente, a interseccional do espaço (urbanidade, classe e raça) pode oferecer um instrumento teórico importante para as análises empreendidas pelas ciências geográficas em particular - e a ciências sociais em geral - sobre a espacialização da pobreza e da violência no Brasil.

\section{O Espaço Urbano Racialmente Produzido}

O que as representações da favela como espaço privilegiado do crime e da desordem têm a nos dizer sobre as relações raciais no Brasil? Ainda que este artigo não ambicione responder a tal pergunta, ela norteia o argumento a ser desenvolvido neste espaço: Existe uma vertente dentro da tradição marxista, desenvolvida a partir de Henry Lefebvre (1991), que concebe o espaço como produto das relações sociais. Para o autor o espaço é sincronicamente um produto social, uma construção mental e um meio de produção; "como meio de produção, o espaço é um meio de controle, e portanto, de dominação, de poder" (1991,p.26). O autor propõe um entendimento do espaço a partir de uma 'tríade conceitual': prática espacial, pela qual o espaço é percebido em suas dimensões físicas; as representações do espaço, ou seja, as maneiras pelas quais o espaço é mentalmente concebido; e espaço representacional, ou seja, onde o espaço é socialmente vivido (LEFEBVRE, 1991, p. 33).

Tal vertente entende a produção do espaço urbano, ainda, como resultado das disputas políticas e econômicas entre as diferentes classes em uma dada sociedade (DAVIS, 2006; HARVEY 2008; LEFEBVRE, 1991; SANTOS, 2007 [1987]; 1994). Ela oferece uma leitura do espaço urbano,

\footnotetext{
${ }^{5}$ Um outro aspecto do controle territorial e da violência paulistana é a presença do PCC - Primeiro Comando da Capital - como autoridade que distribui justiça, proteção e punição entre os moradores da periferia da cidade. Analiso as necropräticas do PCC em outro trabalho. Aquí, por motivo de espaço e por entender que o Estado produz as condições políticas para a violência urbana, o foco da análise são as práticas necropoliticas estatais.
} 
em sua dimensão local e global, como o locus privilegiado da acumulação capitalista e a cidade como uma mercadoria pela qual as elites reestruturam seu poder. Como aponta Mike Davis (2006), o exemplo de demolição de favelas, de dispersão forçada de populações e da hiper-periferização das cidades do chamado terceiro mundo dão a dimensão da lógica espacial de acumulação capitalista. Recentemente, a crise imobiliária nos Estados Unidos, com a corrida bancária pela execução de hipotecas sub-prime, revelou mais uma vez tal dimensão (HARVEY, 2009).

Tais autores têm enfatizado que o "direito à cidade" (HARVEY 2008, p. 23) - isto é, o direito de usufruir dos bens e serviços que a cidade oferece - representa uma das principais dimensões da cidadania urbana. Santos (2007) buscou entender tais dimensões a partir da articulação entre direitos territoriais, direitos culturais e direitos ao entorno, o que chamou de "modelo cívicoterritorial" ou "geografização da cidadania" (SANTOS, 2007, p.150). Para este autor, qualquer discussão sobre os direitos de cidadania não pode prescindir do componente territorial, uma vez que a gestão e organização do território refletem o modelo desigual e hierárquico da sociedade. A cidade seria, nesta perspectiva, repensada a partir de micro-territórios de cidadania permitindose falar não apenas do direito à cidade, mas também do direito ao entorno, dos direitos culturais e dos direitos de participação politica.

Uma revisão do paradigma marxista propõe entendermos a produção do espaço urbano para além do seu aspecto econômico e simbólico. Mark Gottdiener (1985), por exemplo, argumenta que a luta sócio-espacial é configurada também a partir das dimensões de identidade e de pertencimento étnico/racial. Tomando o espaço como categoria dialética pela qual se dá a luta pela hegemonia em uma determinada sociedade, ele enfatiza que as formações espaciais não são meros resultados das forças produtivas, mas são, sobretudo, instrumentos políticos pelos quais a sociedade se reproduz e a luta social se manifesta (GOTTDIENER, 1985, p.127). Tal análise propõe, então, que o espaço não é apenas o resultado das relações de produção, é também resultado de lutas contra-hegemônicas baseadas em fatores como o binômio raça/classe. No Brasil, autores como Lourdes Carril (2003), Raquel Rolnik (1989) e Maura Véras (1997, 2000), sustentam que a configuração territorial da cidade de São Paulo obedeceu a uma lógica de apropriação do espaço público baseada em uma hierarquização social das diferenças. Os discursos higienistas justificavam a segregação dos pobres em áreas distantes do centro uma vez que a favela 
era vista como o locus dos desvios morais e como causa da degradação espacial. Como observa Raquel Rolnik (1989, p. 32-33), o medo do contágio justificou a criação de barreiras físicas e simbólicas contra aqueles tidos como agentes poluidores da estética espacial branca/européia: “as quituteiras devem sair porque 'atrapalham o trânsito'; os mercados devem ser transferidos porque 'afrontam a cultura e conspurcam a cidade'; os pais-de-santo não podem mais trabalhar porque são embusteiros que fingem inspiração por algum ente sobrenatural".

A redefinição territorial da cidade, no pós-abolição empurrou a população negra para regiões precárias de infra-estrutura urbana. A remodelação do antigo centro da cidade de São Paulo, a partir do final do século XIX e início do século XX, fez nascer os "territórios negros" da Barra Funda e do Bixiga. É neste período que se intensifica o processo de segregação residencial por grupos étnico-raciais específicos como os imigrantes europeus de determinados países, a população negra, e os brancos nacionais (ROLNIK 1989, OLIVEIRA 2008, CARRIL 2003, VERAS 2000). De fato, o projeto de modernização empreendido pelo poder público criou um novo mercado imobiliário e um novo padrão de segregação espacial não apenas nas áreas rurais onde os novos imigrantes receberam doações de terras, mas também no espaço urbano. A cidade se transformou em uma fonte de investimento, destino dos lucros acumulados com a escravidão e o impulso da produção cafeeira (COSTA 2003). Obviamente, a ideologia do embranquecimento também teve sua expressão espacial a partir da higienização empreendida pelo Estado contra os cidadãos indesejáveis de então. Se a jovem República se aproximaria dos padrões civilizados e atingiria status de nação desenvolvida à medida que sua população parecesse cada vez mais com o tipo europeu (SKIDMORE 1990, MUNANGA 1999), as cidades deveriam expressar tais mudanças na sua re-configuração territorial.

Em sua análise sobre os modelos de planejamento urbano introduzidos em São Paulo, Costa (2003, p. 100-25) apresenta um balanço das intervenções urbanísticas a partir do final do século XIX quando a nova legislação estabeleceu o primeiro código de posturas municipais. Em 1886 a demolição do velho centro resultou na expulsão da população negra moradora das vilas coletivas na área urbana que mais tarde se transformaria na região predominantemente não-negra do Bixiga, Mooca, Bom Retiro, Barra Funda e Lapa. A elite paulistana tinha, então, dividido a cidade 
em duas: a Nova Cidade - formada por Campos Eliseus, Boulevard Alto Canguaçu, Jardim Aclimação e Higienópolis - e a cidade proletária, em suas adjacências (COSTA 2003; ROLNIK 1989). Portanto, em São Paulo, a distribuição espacial da população obedeceu a interesses específicos, com as classes dominantes assumindo o controle de áreas com uma infraestrutura mais consolidada (Vilhaça 1999, Costa 2003, Véras 2000) e a populacao pobre e não-branca sendo empurrada para áreas marginais. Foi a partir deste processo de expansão da capital que o chamado "quadrante sudoeste" da cidade, e suas áreas adjacentes, se consolidou como o espaço geográfico privilegiado da elite paulistana (VILLAÇA 2001, p.196).

Autores como Reinaldo Oliveria (2008), Tereza Caldeira (2000) e Maura Véras (2003) identificam três processos de segregação espacial na cidade, relativamente semelhantes: o processo de industrialização nas décadas de 1930 e 1940, quando os pobres, sobretudo os nordestinos, ocupam áreas centrais próximas das indústrias e fábricas; a periferização, nas décadas de 1960 e 1970, quando há uma dispersão dos mais pobres para áreas mais distantes do centro, desprovidas de infra-estrutura urbana; e a reconfiguração territorial , nas décadas de 1980 e 1990, quando há um movimento inverso com a população mais pobre vivendo no entorno de áreas urbanas ricas, segregadas por muros (CALDEIRA, 2000, p. 231).

Neste período, a classe média encontrou nos discursos sobre o medo e a violência a estratégia para a criação de uma nova ordem urbanística marcada pela privatização da segurança pública, a apropriação privada dos espaços públicos e a elaboração de sofisticados discursos contra os pobres (idem, p. 258). Esse processo, metaforizado nos muros dos condomínios fechados "não apenas exacerbou a separação dos diferentes grupos sociais, mas também aumentou a tensão e a suspeição entre eles" (CALDEIRA 2003, p. 232). Estes novos enclaves urbanos, com radical reconfiguração da sociabilidade urbana, podem ser entendidos através do que alguns pesquisadores têm chamado de retorno `a "cidade medieval", na qual muros e aparatus de vigilância têm reordenado a vida urbana e transformado algumas áreas das cidades em zonas de exclusão (ALSAYYAD; ROY 2009).

O processo de segregação espacial em São Paulo, no entanto, não pode ser entendido sem levar em conta o papel da categoria "raça" no rearranjamento e controle dos territórios. As políticas estatais de ordenamento urbano têm criado enclaves raciais que embora sejam difíceis de serem 
analisados sob o paradigma da democracia racial brasileira, podem ser facilmente vistos na distribuição e concentração demográfica de brancos e negros em diferentes áreas. Como uma literatura alternativa tem mostrado (VARGAS; ALVES 2009, OLIVEIRA 2008, CARRIL 2003, TELLES 1992), as barreiras de mobilidade espacial em que se encontram os negros não são produtos do acaso. Elas são resultados de práticas cotidianas e arranjamentos institucionais que criam as geografias de raça, violência e pobreza ${ }^{6}$. Ainda que "o modelo de segregação espacial em São Paulo não corresponda ao guetto [estadunidense]" (CARRIL, 2003, p.93) é preciso se atentar para o fato de que (como sugere a tabela 1 ), os negros representam certa homogeneidade quanto a sua localização geográfica na metrópole. Além disso, porque é também como grupo - não apenas como individuos - que os negros vivem a experiência urbana de segregação, violência e morte, é razoavel considerar sua identidade coletiva na composição de territórios específicos na metrópole.

O que previne os negros de romperem a linha da cor e usufruirem do direito à cidade? Qual o lugar dos negros no processo histórico de apropriação do espaço urbano? O que o espaço urbano esconde/revela sobre o padrão brasileiro de relações raciais? Na cidade de São Paulo, os antigos territórios negros das zonas centrais deram lugar a novos conglomerados urbanos expulsando tais populações para áreas distantes como Brasilândia, Jardim Ângela e Cidade Tiradentes (OLIVEIRA, 2008). A partir de entrevistas com antigos moradores dos territórios negros da região central da cidade (como Bixiga e Barra Funda), Oliveira (2008) sugere que o lugar da memória na territorialidade negra é importante porque nos permite entender como a cidade é vivida pelos indivíduos racialmente marcados, quais as estratégias de intervenção territorial, bem como a maneira pela qual tais indivíduos fazem sentido da sua existência urbana. $O$ território aparece aqui não apenas como uma entidade geográfica, mas também, e sobretudo, como lugar dos embates políticos. Ou como elucida Vargas (2005), o espaço urbano é metáfora das relações de poder:

A existência de um espaço neutro, prontamente transparente, é uma ilusão: todos os espaços urbanos são produtos de lutas históricas de poder, e as relações sociais derivadas de tais lutas tornam-se espacializadas de acordo com a ordem política hegemônica (Vargas, 2005, p. 92 [grifo nosso]).

\footnotetext{
${ }^{6}$ Autores como Loic Wacquant (2008) and Marssey \& Denton (1993) têm analisado como as políticas públicas estão implicadas na produção de guetos étnico-raciais nas metrópoles dos Nos Estados Unidos.
} 
Se o espaço urbano é expressão das hierarquias sociais, e se no Brasil tais hierarquias assumem uma dimensão racial, sugerimos então que 'raça' é uma categoria que deve também ser entendida na sua dimensão espacial. O que equivale dizer que em sociedades estruturadas a partir das desigualdades de raça e classe o viver urbano - o direito à cidade - dos grupos sociais é fortemente marcado pelo pertencimento racial e posição social. Dito ainda de outra forma, assim como classe, raça é materializada nas configurações espaciais tanto quanto nossos entendimentos sobre o espaço são marcados por concepções históricas dos significados do ser branco e do ser negro na sociedade brasileira.

\section{Episteme Racial e Governamentalidade Espacial}

Minha ênfase na produção racial do espaço urbano nao é por acaso: ela nos ajuda a entender também como se dá a produção espacial/racial do medo. A imagem que temos da favela como signo do medo e da desordem é marcada por uma "episteme racial" (FANON, 1967) que produz espaços e corpos criminalizados. Temos, então, uma dialética espacial fundada na racialização do medo e na criminalização da raça". Em certa medida, é esta "episteme racial" que orienta a produção material (por meio das intervenções estatais de eliminação seletiva de moradores e das políticas habitacionais desastrosas) e simbólica (na produção acadêmica, nos discursos da classe média, nas narrativas midiáticas da violência) da favela. A esta produção material e simbólica/discursiva que normaliza as concepções que temos de raça e de espaço denomino como - na falta de melhor termo - estratégia territorial de dominação racial.

Autores como James Ferguoson e Akhil Gupta (2002), Sally Merry (2001), Steven Robins (2002) e Rose Reuben (2006) têm analisado estas novas estratégias de gestão do espaço urbano em diferentes regiões do globo a partir do conceito de governamentalidade espacial. Tais autores têm prestado atenção às estratégias de disciplina espacial tais como os programas de vigilância e de polícia comunitária, os programas de treinamentos em direitos humanos e a crescente atuação de Organizações Não-Governamentais (ONGs) em territórios tidos como zonas perigosas.

\footnotetext{
${ }^{7}$ Para uma analise sobre a dialetica entre corpo, crime e racialização, ver Butler, Judith. (1993) Endangered/Endangering: Schematic. Racism and White Paranoia. R. Gooding-Williams (ed.), Reading Rodney King/Reading Urban Uprising,New York and London: Routledge.
} 
O conceito de governamentalidade [governmentality], tal qual originalmente elaborado por Michel Foucault (1991), diz respeito a uma "nova arte de governar" - baseada na tríade: soberania, disciplina e governo. Foucault identifica, a partir do século XVIII, uma mudança paradigmática no exercício do poder soberano. Se antes a autoridade do soberano (o rei) era exercida por meio da punição exemplar, o espetáculo público da morte, a partir de então se inaugurou um novo regime de poder que tomou a vida, e não a morte, como seu fim último. A habilidade dos aparatos de poder de promover a vida, ainda que por meio da imposição calculada da morte a certos grupos, é o que o autor chama de biopoder. Desde então, o foco do exercício do poder moderno se deslocou da morte para a administração calculada e otimizada da vida (FOUCAULT, 1990, p. 136). Na era do biopoder, as técnicas de dominação e controle operam com uma noção de vida completamente diferente: "agora é sobre a vida, ao longo dos seus desdobramentos, que o poder estabelece sua dominação. [O poder moderno opera na] gradual desqualificação da morte (IDEM, IBIDEM, p. 138).

Algumas interpretações do trabalho de Foucault têm sugerido o surgimento de novas tecnologias de governança na era neoliberal (LEMKE, 2001). Se o mercado aparece como o regulador das relações sociais no espaço urbano das metropóles, o urbanismo neoliberal se dá a partir de uma estratégia política de governamentalidade que cria novas espacialidades e novos sujeitos. Nikolas Rose (1999, p. 140) tem refletido sobre estas novas estratégias a partir do conceito de "ético-politica" [ethico-politics]. Agora, como ressalta Rose, o mercado, a família, a comunidade, o indivíduo, são os campos de intervenção estratégica das novas tecnologias de controle. Neste novo "diagrama de poder" (ROSE, 1999, p. 188), todos somos "convidados" a administrar as nossas vidas a partir da racionalidade empresarial: administrar o sucesso e a falência, o risco, participar das cruzadas morais e cívicas em prol da comunidade ${ }^{8}$.

De fato, a cidade neoliberal é o espaço para a promoção de sujeitos disciplinados, conformados ao modelo de cidadania mercantil, responsáveis pelo seu próprio sucesso/falência. A cidade neoliberal é concebida como uma empresa e as políticas públicas

\footnotetext{
${ }^{8}$ Um exemplo destas cruzadas morais e civicas sao os programas "Amigos da Escola”, em que as pessoas sao 'convidadas' a substituir o Estado por meio do trabalho voluntario nas escolas do entorno, ou os programas de delacao premiada criados pela polícia. Comonos lembra Rose, nestes contextos "[o estado] não maisé requeridoa responder às necessidades da sociedade por ordem, segurança, saúde e produtividade. Indivíduos, firmas, organizações, localidades, escolas, parentes, hospitais, mercado imobiliário todos devem tomar para si - como parceiros - a porção de responsabilidade para resolver estas questões (1999, p. 174).
} 
distribuídas a partir da equação custo-benefício. Neste modelo, há um compartilhamento das funções estatais com as ONGs cada vez mais assumindo a gestão da pobreza (SPOZATI, 1988), ou moradores das periferias urbanas incitados a participar de mecanismos de gestão da ordem a partir dos conselhos de segurança, das polícias comunitárias, dos treinamentos em noções básicas de cidadania ${ }^{9}$.

Analisando o caso da cidade de Cape Town, na África do Sul, Steven Robins (2002) observa que o estado neoliberal sul-africano tem empregado novas formas de governança territorial para garantir o controle de certas áreas da cidade tidas como "problemáticas". As políticas de tolerância zero, as estratégias de policiamento comunitário, os condomínios fechados e os novos designs arquitetônicos são algumas das estratégias do urbanismo neoliberal na Cape Town pós- apartheid. No caso das políticas de segurança pública, por exemplo, tais estrategias revelam " a substituição das funções de polícia por um estado neoliberal incapaz de enfrentar o crime com seus próprios meios (ROBINS, 2002, p. 670).

Embora ainda pouco explorado pelas ciências sociais brasileiras, o conceito de governamentalidade espacial - acompanhado de uma crítica aos seus limites epistemológicos - nos permitiria entender as estratégias territoriais de dominação em um contexto marcado por uma ordem urbana estruturada na simbiose violência, raça e classe. Para além de denunciar o aspecto despótico da gestão da ordem urbana - herdado do período militar - que justifica a eliminação de certos "inimigos internos" como forma de pacificação social (SEABRA 1990, PINHEIRO 1991, CALDEIRA 2000, SINHORETTO 2002), as ciências sociais/geográficas poderiam ajudar a desvendar também as estratégias políticas de controle e gestão de populações e territórios tidos como zonas perigosas. Não por acaso, o arbítrio policial e formas parelalas de controle ocupam lugar de destaque na vida dos moradores das periferias urbanas. É neste sentido que se pode afirmar que a favela se converteu no espaço paradigmático para o exercício de uma peculiar economia da violência: a distribuição calculada da morte e da punição como instrumentos políticos de controle territorial. Isso equivale a sustentar que, no caso brasileiro, a nova "arte de governar" que Foucault (1991)

\footnotetext{
${ }^{9}$ Para uma rica análise dos processos de implantação dos Conselhos de Seguranca, ver Galeano Cruz, A. Para Falar em Nome da Seguranca: o que pensam, querem e fazem os representantes dos Conselhos Comunitarios de Seguranca. Tese de doutorado, Universidade Estadual de Campinas.
} 
acreditou suplantar os mecanismos despóticos do poder soberano tem racionalidades múltiplas: ela opera simultaneamente na produção espacial da favela como lugar da desordem e do crime (biopoder), na disciplina espaco-corporal a partir do trabalho "pedagógico" de conselhos comunitários de segurança e das ONGs com foco nos jovens tidos como "problema social", e nas intervenções estatais letais (necropráticas), como dão conta as ações policiais resultantes nos famigerados "autos de resistência" ou "resistência seguida de morte". A morte aparece, na favela, como parte do cotidiano dos seus moradores e a violência estatal, em suas múltiplas dimensões, se incorpora também como estratégia seletiva de contenção social. Controlar as geografias racializadas da cidade por meio desta tática ${ }^{10}$ parece ser uma maneira "eficiente" para o estado neoliberal restabelecer seu poder sobre aqueles vistos como uma ameaça ao movimento livre dos "cidadãos" e do capital.

\section{Necropespectivas Espaciais}

Para entender tais mecanismos de distribuição desigual - intencional ou não - da morte no espaço urbano da cidade de São Paulo, utilizo o conceito de "necropolítica" desenvolvido pelo filósofo camaronês Achille Mbembe (2003). O termo, tal qual empregado pelo autor, expande o conceito de biopoder, proposto por Michael Foucault (1990, 1991, 2003, 2008), ao descrever os mecanismos de controle e gestão da vida em sociedades marcadas por 'topografias da crueldade' (BALIBAR, 2001) como sugere a realidade urbana brasileira. Biopoder e necropoder não são apenas interfaces conceituais. Se biopoder diz respeito à produção calculada e otimizada da vida, necropoder enfatiza a primazia da morte como estratégia de exercício do poder moderno em territórios e populações tidos como ameaça latente. Não que tal categoria esteja em oposição ao conceito empreendido por Foucault - uma vez que o biopoder diz respeito precisamente à imposição da morte em nome da vida - , mas ela capta com mais precisão a centralidade da morte na experiência urbana das populações empobrecidas brasileiras (ALVES 2010) ${ }^{11}$. Uma análise crítica de tais categorias nos permite dizer que alguns corpos e alguns territórios

\footnotetext{
${ }^{10}$ As Unidades de Polícia Pacificadora (UPPs) no Rio de Janeiro e as Bases Comunitárias de Segurança em São Paulo são exemplos das novas técnicas de governança territorial. Novas pesquisas poderiam investigar os custos da paz social a ser 'conquistada' nestes territórios por meio da articulação entre polícia, ONGs, Igrejas, o que sugere uma nova pratica de governamentalidade com velhos modus operandis.

${ }^{11}$ Agradeço a Leandro Siqueira por chamar a atenção para outros aspectos desta interface (tanatopolitica/vitalpolitica) em: Alves, Jaime \& Siqueira, Leandro. "Os massacres se tornaram vitais": : O terror policial como política de segurança pública em São Paulo (mimeo).
} 
racializados recebem a preferência na distribuição das chances de vida e de morte. Portanto, a noção de necropolítica desenvolvida por Mbembe, ainda que utilizada em outro contexto, nos parece mais apropriada para dar conta da experiência de negras e negros em seus encontros mortais com o Estado porque tal noção explicita os limites das tecnologias de governamentalidade neoliberal em lidar com as dinâmicas espaciais urbanas em sociedades estruturadas na dominação racial.

Quando aplicado ao caso brasileiro, onde a violência homicida, o terror policial, e as condições de pobreza e vulnerabilidade sugerem uma "antropofagia racial", caberia a sugestão de Mbembe de reivindicar as categorias "necropoder" e "necropolítica" para descrever a relação histórica entre o Estado e as populações racializadas. O modus operandi da polícia brasileira sugere que quando confrontado com corpos negros, o poder de soberania - o poder de decider quem vive e quem morre - se converte tão somente no direito de fazer morrer: não há espaço para a produção de corpos dóceis porque trata-se de corpos-vazios, matáveis ${ }^{12}$. Neste contexto, alguns territórios ambientam a "topografia da crueldade" e algumas populações figuram como não-cidadãos, ou numa análise mais otimista, como cidadãos de segunda categoría. Aqui, a distribuição calculada da morte é o que se configura como a (necro)política moderna de gestão e controle de territórios e corpos vistos como violentos. Como nos lembra Mbembe (2003, p.34), " novas tecnologias de destruição estão menos preocupadas em conformar os corpos em aparatos disciplinares que (...) conformá-los à ordem da máxima economia representada pelo massacre".

As figuras apresentadas abaixo dão uma dimensão dos padrões persistentes de vulnerabilidade social de negros e negras ${ }^{13}$ no espaço urbano paulistano. Analisados a partir das categorias conceituais propostas, elas revelam aspectos menos visíveis (embora não menos perversas) da violência estatal, expressas na negação de direitos básicos, na segregação espacial e na persistência da pobreza em areas predominantemente negras. As figuras 01 e 02 abaixo representam, respectivamente, os distritos da capital paulista de acordo com a sua composição racial e renda familiar. O mapa racial evidencia a distribuição territorial da

\footnotetext{
12 Obviamente estou em diálogo não apenas com Mbembe (2003) mas também com Giorgio Agamben (1998) e seu conceito de homo sacer, aquele cuja precária posição perante a Lei o torna matável, sem que sua morte seja um crime. Os limites das reflexões eurocêntricas de Agamben são explicitados precisamente por Mbembe em sua análise sobre realidades racializadas fora da Europa. Se o campo de concentração nazista foi o espaço paradigmático do biopoder, como argumenta Agamben, qual o lugar do Atlântico Negro ( bem como a escravidão, o genocídio indígena e as práticas de dominação modernas) em tal regime de poder?

${ }^{13}$ Neste artigo tomo o termo negro/negra como categoria política tal qual adotada pelo movimento negro em seus embates com o Estado. O termo também é usado pelo IBGE associando as categorias preto e pardo como grupo homogênio.
} 
população negra no município a partir de dados do Censo 2000. O Mapa da Vulnerabilidade Juvenil, organizado pela Fundação Seade, agrega indicadores sociais tais como desemprego, desigualdades educacionais, gravidez precoce, homicídios e morte prematura.

Nota-se que, lidos em conjunto, os mapas ajudam o/a leitor/a a visualizar a articulação perversa entre vulnerabilidade social e raça no espaço urbano de São Paulo. As áreas verdes e cinzas no mapa representam, respectivamente, os dois grupos de distritos onde os padrões de vulnerabilidade são mais acentuados, em contraste com as áreas azuis com o menor índice de pobreza. Nas áreas verdes, o número de jovens fora da escola é duas vezes maior do que o registrado nas áreas mais ricas (respectivamente 14\% e 7\%). Também, nos distritos mais pobres o índice de maternidade precoce é bem maior: a cada 1.000 jovens de 14 a 17 anos, 19 tiveram filhos nas áreas mais ricas e 41 nas regiões mais pobres. Nesses distritos, as taxas de homicídios entre jovens de 15 a 24 anos continuam elevadas, embora tenha havido uma redução de $38 \%$ no número de óbitos entre 2000-2005. Ainda segundo o Mapa da Vulnerabilidade Juvenil, a média é de 189,4 óbitos por 100 mil habitantes, uma taxa 3,3 vezes maior que a registrada nas regiões mais ricas, onde a taxa de homicídios entre jovens na mesma faixa etária é de 57,1/100 mil habitantes.
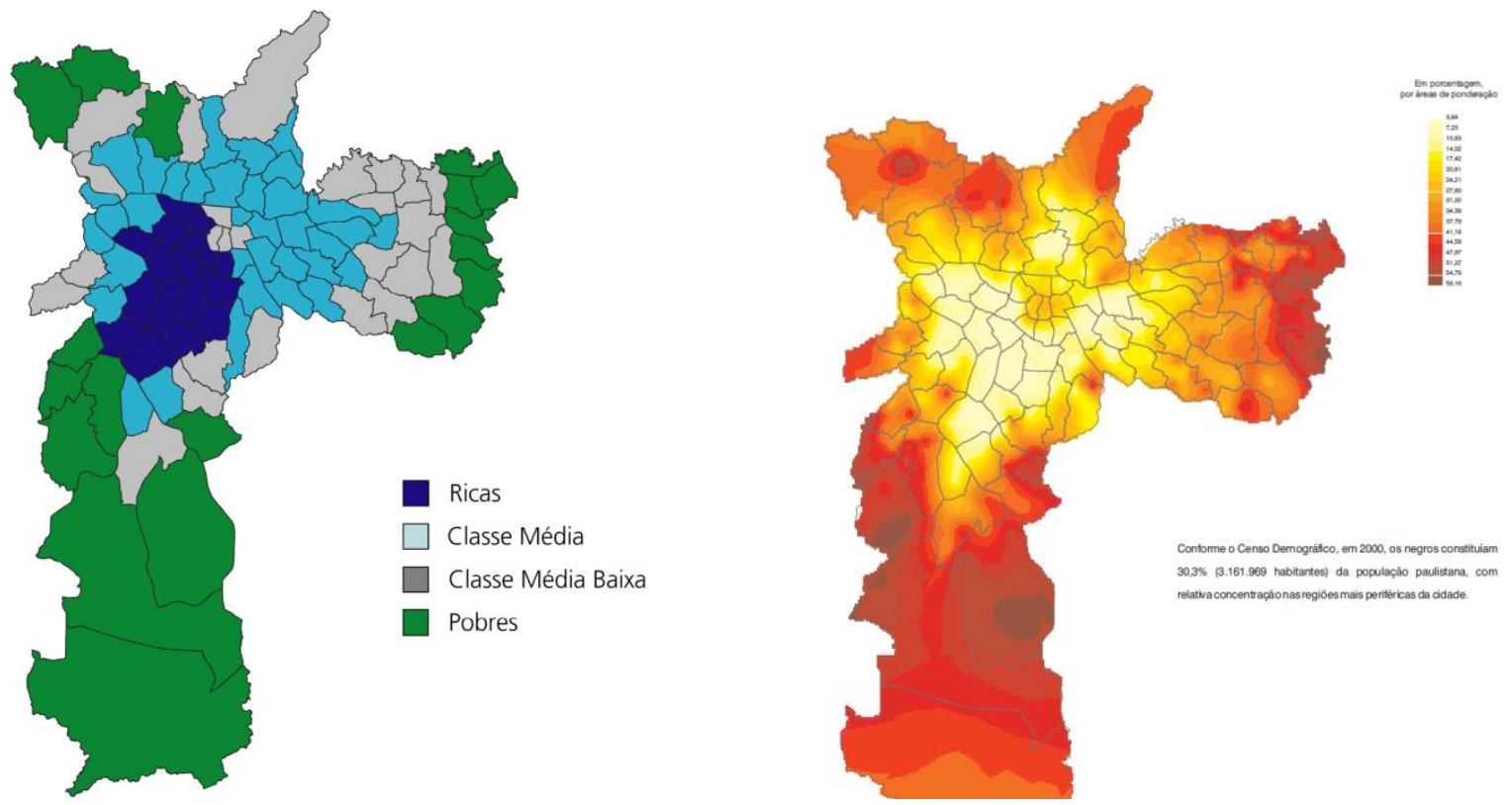

Figura 01 e 02 - Territórios Negros e Mapa da Vulnerabilidade Social Juvenil Fonte: SEMPLA/Prefeitura Municipal de São Paulo e Fundação Seade. Disponivel em http://infocidade.prefeitura.sp.gov.br/

Há uma nítida concentração dos negros nas áreas mais distantes do centro, principalmente nos 
extremos das regiões Sul e Leste do município. Enquanto negros representam em média $30 \%$ da população paulistana, sua presença está sobrerrepresentada nos distritos residenciais mais desprovidos de infra-estrutura urbana; é o caso, por exemplo, de distritos como Cidade Tiradentes (51.4\%), Jardim Ângela (49.8\%) e Brasilândia (39.7\%). Inversamente, a população branca representa em media $90 \%$ da composição demográfica de distritos como Itaim Bibi $(90,1 \%)$, Moema $(91,9 \%)$ e Perdizes $(90,1 \%)$, localizados no chamado "quadrante sudoeste" da cidade. A tabela abaixo revela a distribuição demográfica dos dois grupos populacionais (negros e brancos) nos dez distritos com melhores e piores indicadores de vulnerabilidade social. Se é verdade que nos distritos mais vulneráveis há certa diversidade na composição demográfica da população, com negros ${ }^{14}$ e brancos convivendo no mesmo espaço, o mesmo não acontece nos bairros com os melhores indicadores sociais. Além disso, em termos proporcionais os negros estão sobrerrepresentados nos primeiros e subrrepresentados nos últimos quando comparados com a sua média municipal (28\%).

Tabela 1 - Distribuição espacial da população por raça em dez distritos da Cidade de São Paulo/Brasil

\begin{tabular}{ccccc|cccc}
\hline \multicolumn{4}{c|}{ Distritos mais socialmente vulneráveis } & \multicolumn{3}{c}{ Distritos menos socialmente vulneráveis } \\
\hline Rank & Distrito & $\begin{array}{c}\text { Brancos } \\
\text { (\%) }\end{array}$ & $\begin{array}{c}\text { Negros } \\
\text { (\%) }\end{array}$ & $\begin{array}{c}\text { População } \\
\text { total }\end{array}$ & Distrito & $\begin{array}{c}\text { Brancos } \\
\text { (\%) }\end{array}$ & $\begin{array}{c}\text { Negros } \\
\text { (\%) }\end{array}$ & $\begin{array}{c}\text { População } \\
\text { Total }\end{array}$ \\
\hline 1 & Marsilac & 58,6 & 40,2 & 8.398 & Jd. Paulista & 90,9 & 5,2 & 83.663 \\
2 & Iguatemi & 63,3 & 36,1 & 101.772 & Moema & 91,9 & 4,7 & 71.269 \\
3 & C. Tirdentes & 49,4 & 49,8 & 190.652 & Pinheiros & 88,4 & 7,2 & 62.991 \\
4 & Grajaú & 49,6 & 48,8 & 334.283 & Consolacao & 87.9 & 8.3 & 54.518 \\
5 & Jd. Ângela & 47,2 & 51,4 & 245.799 & Itaim Bibi & 90,1 & 6,5 & 81.450 \\
6 & Parelheiros & 49,7 & 48.5 & 102.830 & Perdizes & 90,1 & 7,0 & 102.440 \\
7 & I. Paulista & 50,2 & 48.5 & 212.727 & V. Mariana & 83,5 & 7,2 & 123.677 \\
8 & Brasilandia & 58,4 & 39.7 & 247.322 & S. Amaro & 89.3 & 6,9 & 60.533 \\
9 & C. Ademar & 56,1 & 41.5 & 243.367 & Mooca & 89.9 & 7,1 & 63.274 \\
10 & Guaianazes & 51,8 & 47.3 & 98.539 & Morumbi & 81.6 & 14,7 & 34.581 \\
\hline
\end{tabular}

Fonte: IBGE/Censo 2000 e Indice de Vulnerabilidade Juvenil 2000-2005, Fundação SEADE, 2007. Tabulação: Vargas, J and Amparo_Alves, J. Geographies of Death. an intersectional analysis of police lethality and the racialized regimes of citizenship in São Paulo. Ethnic and Racial Studies, v. 33, n. 4, p. 590-610, 2009.

Uma vez identificados os territórios por composição racial e padrões de pobreza, vale a pena perguntar: existe uma correlação entre os distritos predominantemente negros e a distribuição das mortes no município? Os dados oficiais sobre a violência homicida na cidade de São

\footnotetext{
${ }^{14}$ Utilizamos a categoria 'negro' como a soma de pretos e pardos, conforme metodologia do IBGE. Od dados se referem ao censo do ano de 2000.
} 
Paulo entre os anos 2003 e 2008 nos permitem dizer que $\operatorname{sim}^{15}$. Embora o fator "raça" ainda seja subnotificado nas estatísticas sobre violência no estado de São Paulo - o que compromete a abrangência de uma análise puramente baseada em dados oficiais -, a notificação sobre homicídios apresenta razoáveis graus de confiabilidade, dada a exigência do registro em órgãos públicos como o sistema DATASUS do Ministério da Saúde ${ }^{16}$. O padrão de homicídios no município apresenta algumas características comuns a outras cidades brasileiras: concentração majoritária entre homens, idade entre 15 e 29 anos, negros, moradores de áreas urbanas periféricas (WAISELFISZ, 2011).

Embora nos últimos anos as estatísticas oficiais da Secretaria de Segurança Pública dêem conta de uma redução de $70 \%$ no número de homicídios, os números exigem cautela uma vez que esta redução nao se dá de forma homogênea na geografia da cidade. Persiste, por exemplo, a concentração da violência letal por homicídios nos distritos cujos indicadores sociais são os mais precários. O gráfico abaixo demonstra a distribuição espacial das mortes por causas externas em vinte distritos da cidade de São Paulo. A escolha de tais distritos se deu a partir da sua localização no rank do Índice da Vulnerabilidade Juvenil, da Fundação Seade ${ }^{17}$. O levantamento seriado dos casos de homicídios entre 2003 e 2008, foi feito com base no banco de dados do sistema tabnet do Programa de Aprimoramento de Informações Vitais (PRO-AIM) da Secretaria Municipal da Saúde do Município de São Paulo.

No período analisado foram registrados 16421 óbitos por homicídio na cidade de São Paulo, assim identificados: 8115 brancos, 8119 negros (pretos e pardos), 59 amarelos, 4 indígenas e 124 não identificados. Chama a atenção no gráfico os picos de homicídios em bairros cuja população negra esta sobrerrepresentada quando comparada com sua participação demográfica na cidade de São Paulo. É o caso de Grajaú, com 985 homicídios no período (417 entre brancos e 566 entre negros), Jardim Ângela com 665 homicídios (284 entre brancos e 375 entre negros) e Brasilândia que registrou 605 mortes por homicídios, (sendo 301 entre brancos e 298 entre negros). Inversamente, nos distritos com população majoritariamente branca, como é o caso

\footnotetext{
${ }^{15}$ Minha análise e' consistente - e em diálogo- com os trabalhos de Maria Inês Barbosa (1998) e Luis Eduardo Batista (2003) quem têm identificado uma correlação semelhante entre raça e vulnerabilidade a morte em São Paulo. Tais trabalhos têm o merito de ter inaugurado novas perspectivas de analises sobre o fator raca nas políticas de saude publica em Sao Paulo.

${ }^{16}$ A partir de 2011, o Sistema DATASUS passou a integrar a Secretaria de Gestão Estratégica e Participativa, conforme Decreto n 7.530 de 21 de julho de 2011 que trata da Estrutura Regimental do Ministério da Saude.

17 No Mapa da Vulnerabilidade Juvenil, os distritos foram concentrados em areas homogeneas de acordo com os graus de vulnerabilidade em que 0 representa o distrito com o menor grau e 100 o de maior.
} 
de Jardim Paulista (90,9\%), Itaim Bibi $(90,1 \%)$ e Moema $(91,9 \%)$, as taxas de homicídios estão abaixo da média municipal. Em números absolutos, o distrito de Itaim Bibi, por exemplo, registrou 18 homicídios no período (12 vítimas brancas e 6 negras).

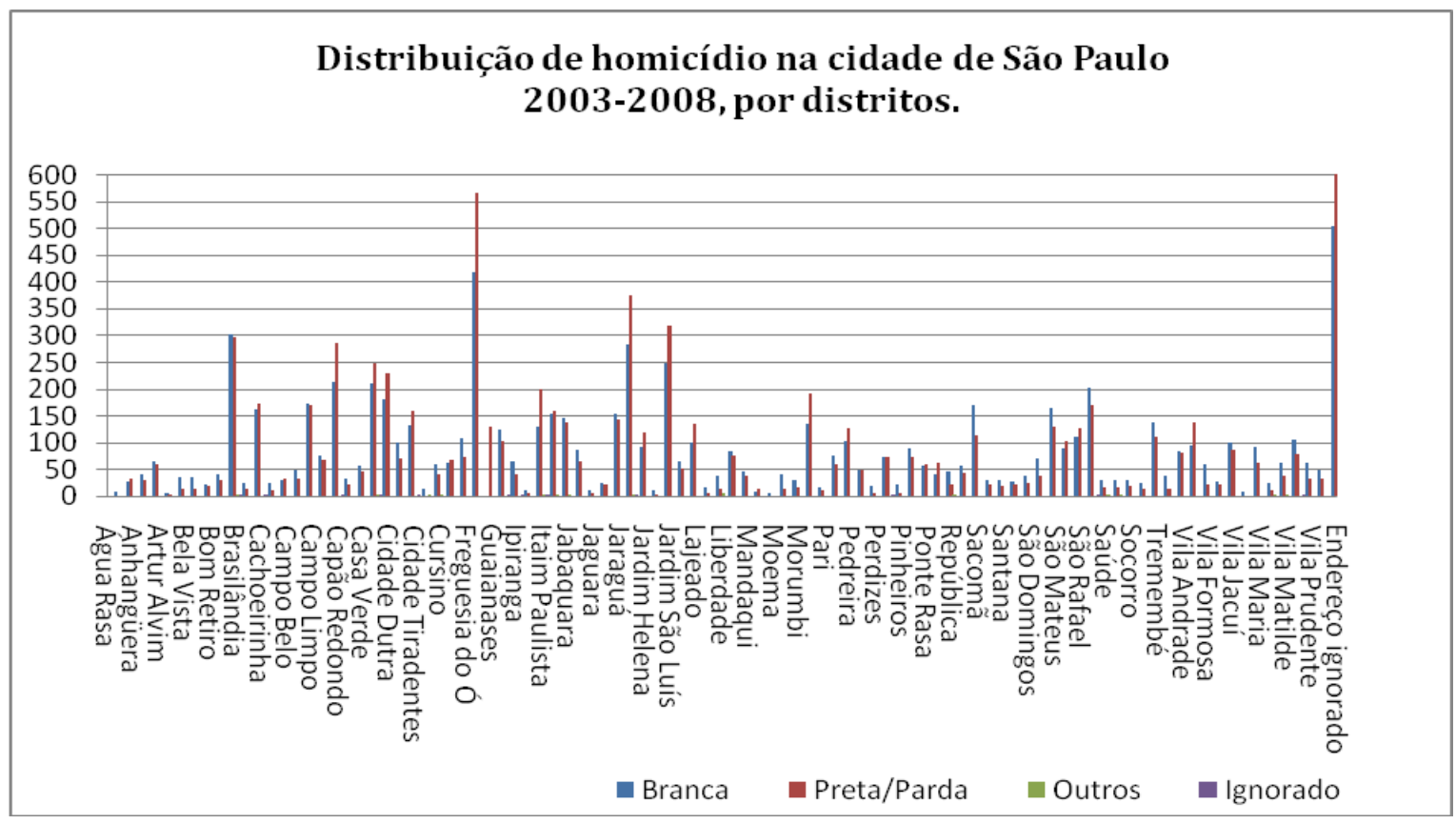

Figura 03 - Distribuição espacial da violência homicida Fonte: PRO-AIM/Secretaria Municipal da Saúde/PMSP. Nota: tabulação feita pelo autor a partir dos dados consolidados de 2003 a 2008. Os dados estão disponíveis em: http://ww2.prefeitura.sp.gov.br/cgi/deftohtm.exe?secretarias/saude/TABNET/SIM/obito.def

Já nos distritos onde a população negra é proporcionalmente maior - como Cidade Tiradentes (49,8\%), Grajaú $(48,8)$ e Brasilândia $(39,7)$ - os índices de mortes violentas aumentam drasticamente com uma crescente vitimização também de brancos, como indica o gráfico. Uma possível explicação para esse fato é que se a violência letal incide com maior freqüência sobre a população negra, brancos convivendo no mesmo espaço estão tambem vulneráveis à morte. Inversamente, nos bairros de presença predominantemente branca há uma mudança no padrão de vitimização, com taxas reduzidas de mortes. Há, portanto, um rastro da violência letal/homicida que se concentra nas áreas predominantemente negras e que, embora tenham os negros como seus principais alvos, também transforma os brancos vivendo em tais áreas em potenciais vítimas. O corpo negro aparece, portanto, como o catalizador de um tipo de morte (violência homicida) que incide de maneira preferencial, embora não exclusiva, sobre os negros, 
pavimentando o caminho para a vitimização de outros grupos. A vitimização branca seria, nesse sentido, uma consequência da banalização da morte negra ${ }^{18}$.

O mapa abaixo mostra a concentração de homicídios entre jovens na série histórica 1996- 2000, na cidade de São Paulo. As áreas mais escuras do mapa são aquelas cujas taxas de mortes por homicídios estão acima de 150 por cada grupo de 100 mil habitantes. As áreas mais claras, por sua vez, registraram no período uma taxa de 0-25 óbitos por homicídios para cada grupo de 100 mil habitantes. A figura aponta para a persistência da violência letal em específicas áreas urbanas, mais especificamente aquelas áreas distantes do centro, onde o padrão de pobreza é mais acentuado.

Quando analisado levando em consideração a distribuição espacial da população negra, delineada na tabela 01, nota-se uma persistência histórica da sobreposição entre concentração demográfica negra, pobreza e violência homicida. Em contraposição, a área mais clara do mapa é aquela cuja presença branca esta sobrerrepresentada, isto é, as áreas centrais do município, principalmente o chamado sudoeste paulistano.

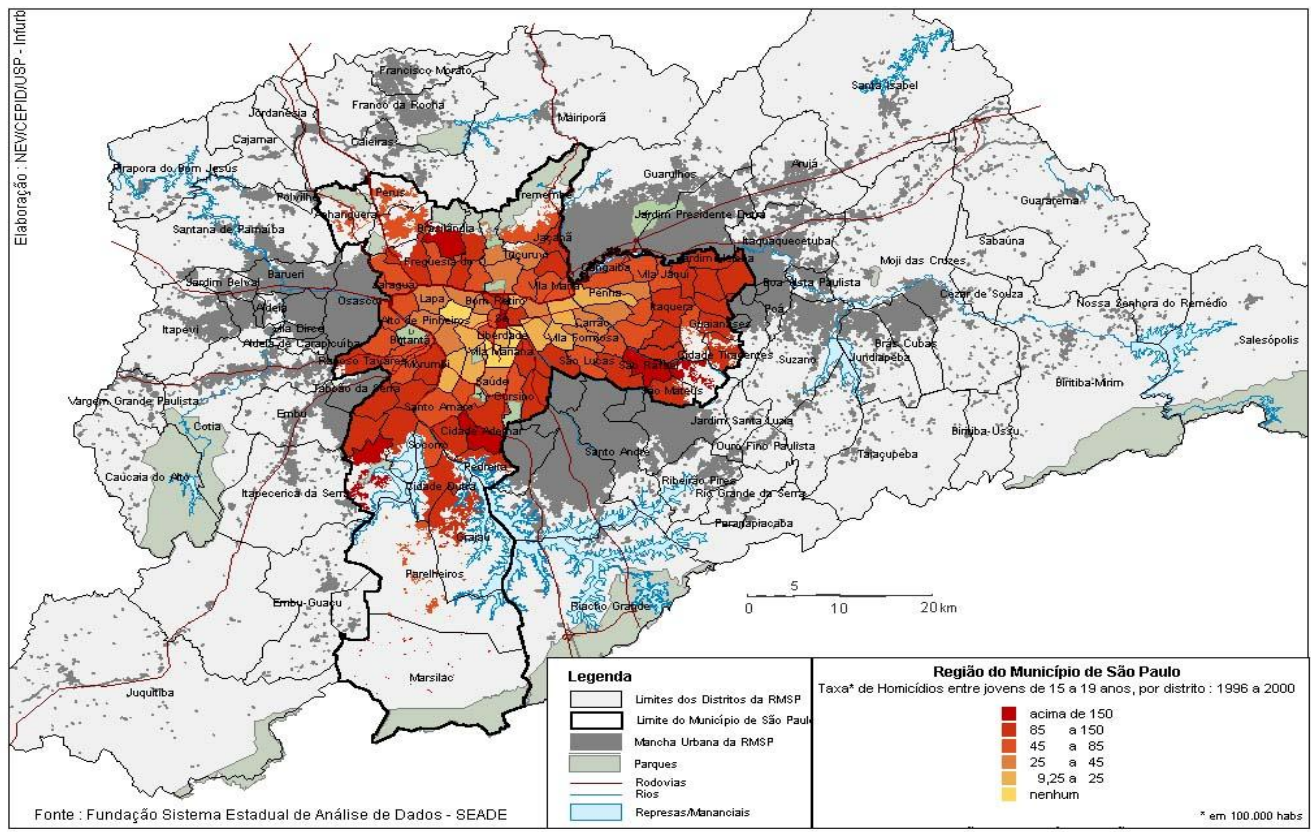

Figura 04: Taxa de homicídios entre jovens (15-19 anos) nos distritos da cidade de São Paulo Fonte: NEV- Núcleo de Estudos da Violência, Universidade de São Paulo (USP). Disponível em: http://mapas.nevusp.org/

\footnotetext{
${ }^{18}$ Agradeco a João Costa Vargas e a Charlie Hale pelas observacoes sobre as disposições anti-negras e a vitimização branca, um aspecto ainda pouco explorado nas investigações sobre a violência urbana no Brasil (comunicacao pessoal).
} 
Um outro indicador importante no delineamento da espacialização da morte na cidade pode ser a identificação dos serviços de infra-estrutura urbana. A saúde da população negra tem sido objeto de estudo de pesquisadores que têm identificado a persistência de determinadas doenças e o impacto das desigualdades sociais no acesso aos serviços médicos essenciais entre este grupo populacional. Foge ao escopo deste artigo a discussão sobre a prevalência de determinadas causas mortis entre a população negra - tais como a mortalidade materna feminina por complicações no parto, as doenças infecciosas e parasitárias, e principalmente as mortes por causas externas (ALVES 2010, SANTOS 2010, BATISTA 2003, BARBOSA 1998).

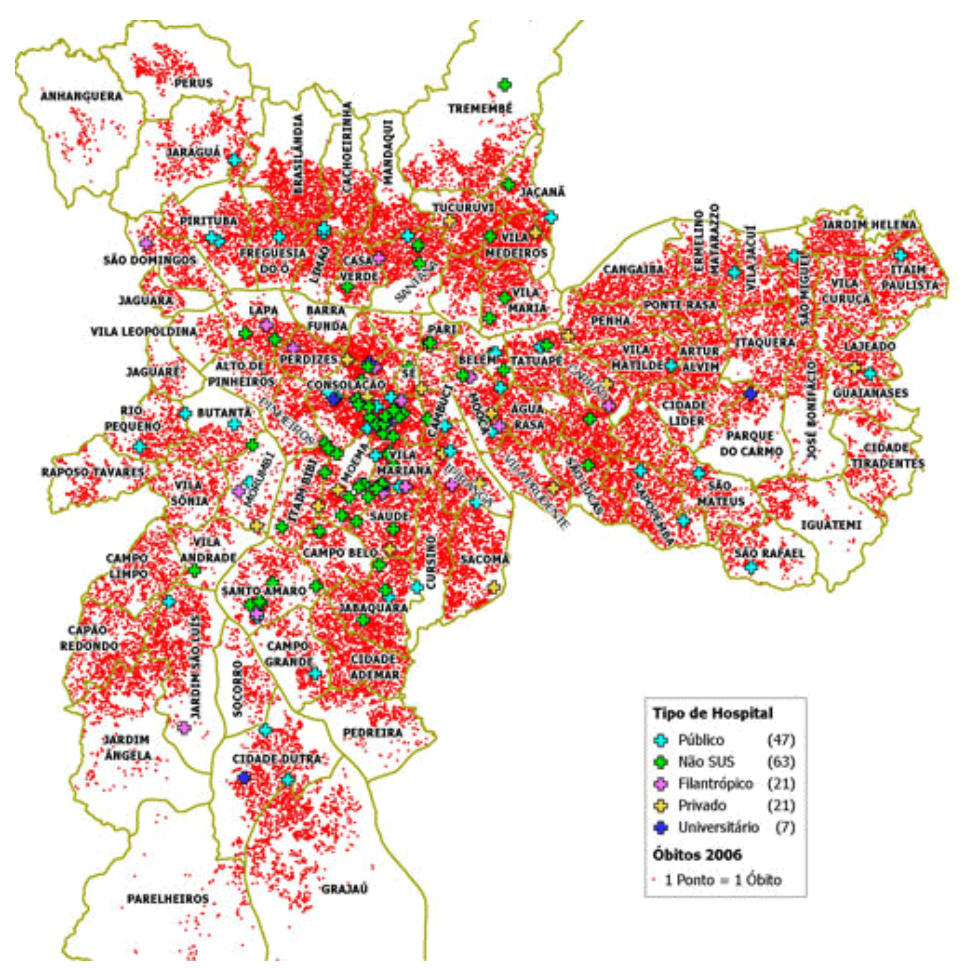

Figura 04: Óbitos gerais e oferta de hospitais na cidade de São Paulo, 2006 Fonte: Atlas da Saúde, Hospital Albert Einstein de São Paulo (SD\&W). Disponível em: http://apps.einstein.br/atlas/2008 basicos redeservicos.asp?ano=5\&id1=0\&id2=2

Interessa-nos aqui é notar a incidência de óbitos gerais e a distribuição da oferta de hospitais na cidade de São Paulo: em 2006, o município contava com 159 hospitais, dos quais 46 eram públicos. Como pode ser observado no mapa acima, a maior oferta de leitos hospitalares se dá nas regiões centrais da cidade. As áreas com alta densidade populacional como o extremo sul e o extremo leste são as mais desprovidas. Até 2007, o distrito de Cidade Tiradentes, um dos mais populosos da cidade, não contava com um único hospital público ou privado. No outro 
extremo da cidade, somente em 2008 a região de M' Boi Mirim passou a contar com o seu único hospital público. Com aproximadamente 3 milhões de habitantes, a Zona Sul conta hoje com apenas cinco unidades hospitalares e três mil leitos (SEMPLA, 2010).

A análise da distribuição espacial da oferta dos serviços de saúde é importante porque nas conversações sobre violência estatal têm se enfatizado sobremaneira a violência policial como a manifestação mais explícita - e por isso a que mereceria maior atenção - de violação dos direitos humanos no Brasil. Na tentativa de desmistificar tais narrativas, este artigo toma a violência estatal como todo ato "tolerado ou incentivado pelo estado com a finalidade de criar, justificar, explicar ou reproduzir hierarquias de diferença e relações de desigualdades. São atos de violência estatal, mesmo que o estado não apareça diretamente como seu agente primário" (NAGENGAST, 1994, p. 114). Nesse sentido, a negação do direito fundamental à saúde pode ser visto como uma das faces da violência estatal contra as populações moradoras de áreas pobres urbanas predominantemente negras.

Ainda assim, a violência policial assume uma dimensão especial por se tratar de uma manifestação explícita de dominação estatal sobre determinados grupos, ainda que per si o Estado não subscreva tais práticas em seus ordenamentos juridicos. Em última análise, ao assumir o terror como prática sistemática de contenção social, os policiais se confundem com o Estado; a polícia tem sido historicamente, na verdade, o principal elo entre o Estado e suas populações marginalizadas (PINHEIRO, 1991, SILVA 1998, ADORNO 1995).

Um dos desafios na análise dos dados oficiais sobre a letalidade da ação policial é que geralmente os números carecem de confiabilidade no que diz respeito à $\operatorname{cor}^{19}$ e região de origem dos mortos. Em meu trabalho de campo na Ouvidoria da Polícia do Estado de São Paulo, em 2010, notei uma inconsistência entre a cor dos mortos quando contrastados os diferentes documentos dos processos acompanhados pela instituição: Boletins de Ocorrência (B.O.), laudo necroscópico, Inquérito Policial Militar ${ }^{20}$. Os registros na Ouvidoria, no entanto, permitem afirmar que as vias públicas da periferia paulistana são os locais que ambientam com mais

\footnotetext{
${ }^{19}$ Sintomático disso é que nem mesmo os relatórios das organizações internacionais de direitos humanos trazem dados por cor. De acordo com a Human Rights Watch (2009), foram mortas onze mil pessoas nos últimos seis anos pelas polícias de São Paulo e Rio de Janeiro. A cor dos mortos, no entanto, é raramente mencionada nos relatórios, o que aponta também para os limites do paradigma de direitos humanos como categoria universal.

${ }^{20} \mathrm{Em}$ minhas observações chamou-me a atenção o fato de que nos Boletins de Ocorrencia, a autoridade policial geralmente aparece como vítima e os individuos mortos como acusados pelo crime de 'resistência'. Desconheço pesquisa acadêmica discutindo as implicações políticas de tais práticas.
} 
frequência as ações letais da polícia. Em São Paulo, foram 371 mortes pela Polícia Militar sob a rubrica "Resistência Seguida de Morte" em 2008, outras 397 em 2009, e 568 mortes em $2010^{21}$. Nos últimos cinco anos (2005-2009) as forças policiais do estado mataram 2176 pessoas sob tais justificativas. No mesmo período toda a África do Sul registrou 1623 mortes sob a mesma alegação. Somente a Rondas Ostensivas Tobias Aguiar (ROTA) foi responsável por 350 autos de resistência seguidos de morte no período (Human Rights Watch, 2009, p.31-40).

O Mapa do Extermínio, elaborado por organizações de direitos humanos em São Paulo confirma esta tendência ao identificar o perfil dos mortos pela polícia: homem, jovem, negro e morador das áreas pobres do município (SÃO PAULO 2009, OVP 2011). A partir de dados da imprensa, o Mapa revela uma "metodologia da morte" em que local de moradia, idade, raça e gênero aparecem como condicionantes da violência policial. São as regiões Leste e Sul as que apresentam a maioria das ocorrências letais envolvendo policiais civis e militares em São Paulo. Em 2006, por exemplo, os dois distritos policiais líderes em ocorrências fatais por policiais foram o 49응 DP em São Mateus (Zona Leste) e o 47ㅇ DP, em Capão Redondo, na Zona Sul (CSDDH, 2009).

O mapa abaixo, por sua vez, expressa a espacialização da atuação dos grupos de extermínio (esquadrões da morte) no município de São Paulo entre 1980 e 2006. Desenvolvido pelo Núcleo de Violência da Universidade de São Paulo - USP (NEV), a partir de dados da imprensa sobre chacinas no município, a figura indica as áreas de maior incidência de execuções sumárias no período, praticadas, sobretudo por policiais civis e militares. Os dados corroboram também com as denúncias de organizações de direitos humanos apontando no mesmo período um "padrão de ação policial baseado em uma política de extermínio sem precedentes" (São Paulo, 2005, p.5). Enquanto se pode argumentar que a violência homicida esteja pulverizada em todas as regiões da cidade, é possível identificarmos uma distribuição desigual da morte, em que os territórios distantes da região central (as áreas mais escuras do mapa) concentram as maiores taxas de execuções extra- judiciais, enquanto o centro expandido e o sudoeste paulistano (área predominantemente branca) apresentam os menores índices de ocorrência desta natureza. Se sobrepormos os números da violência policial ao mapa demográfico da população negra e

\footnotetext{
${ }^{21}$ Osdados sao baseadosnos relatorios trimestrais e anuais, 2010 e 2011. Disponíveis em: <http://www.ouvidoria-policia.sp.gov.br/pages/Relatorios.htm>. Acesso em: 20 mai 2011.
} 
ao índice de vulnerabilidade juvenil (ver figuras 01 e 02 acima) teremos então uma "geografia da morte" (VARGAS; ALVES 2009) delineada por raça, classe e local de residência.

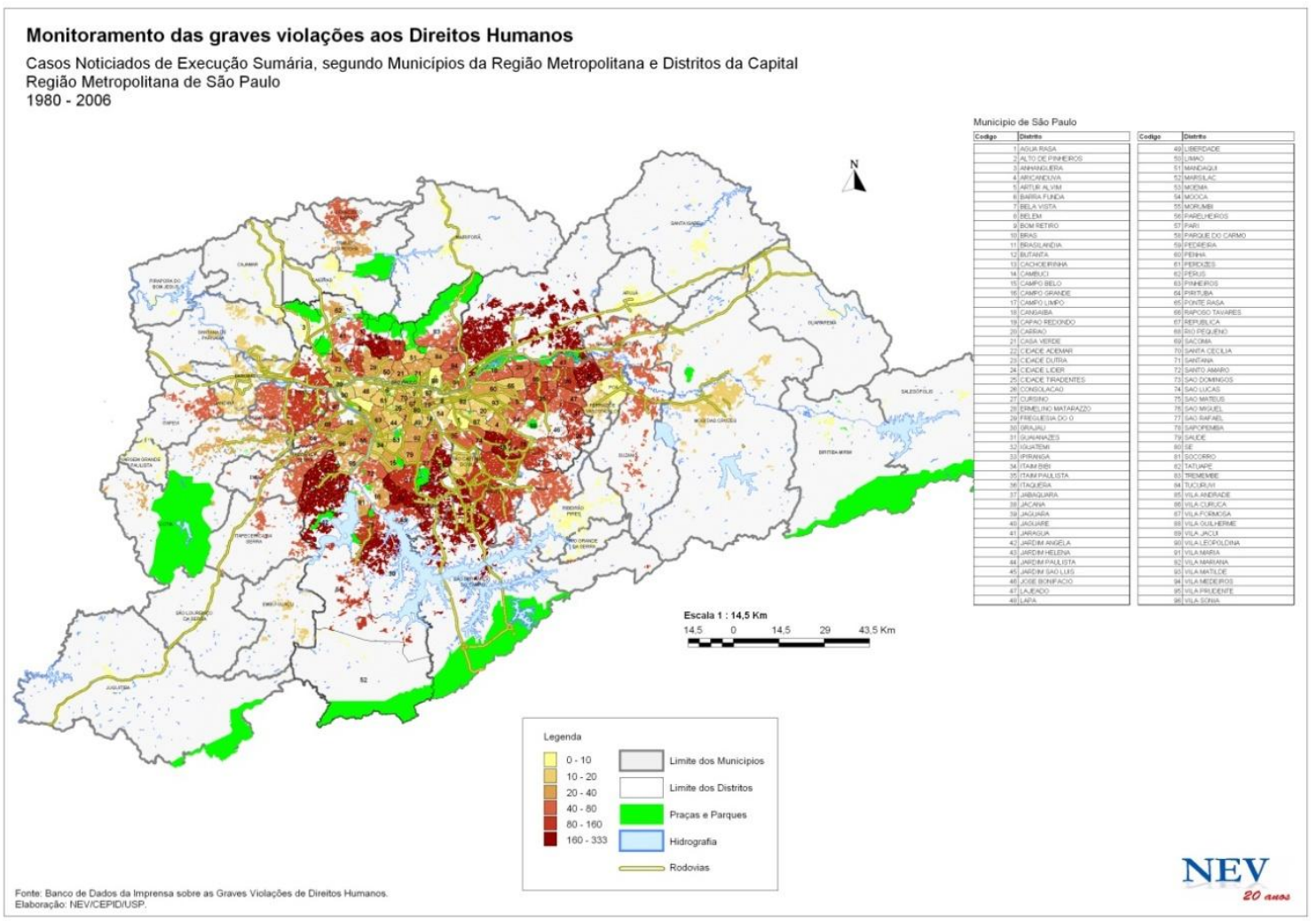

Figura 05: Execuções Sumárias no Município de São Paulo (1980-2006).

Fonte: NEV- Núcleo de Estudos da Violência, Universidade de São Paulo (USP). Disponivel em: http://mapas.nevusp.org/

Como têm mostrado algunos estudiosos da violência urbana ((MUSUMECl et al 2006, SILVA 1998, ADORNO 1995, CANO 1997, HUMAN RIGHTS WATCH, 2009, WAISELFISZ 2011), as justificativas oficiais para as altas taxas de letalidade pela policía nas favelas brasileiras são as mais variadas e criativas possíveis. Uma explicação comum é que em tais áreas o crime é mais intenso e, portanto, o confronto é não apenas necessário como legítimo. Nos relatórios oficiais, a palavra "confronto" e o rótulo "resistência seguida de morte" ou "autos de resistência" justificam as mortes de civis e selam o destino dos processos envolvendo policiais. Diz-se, ainda, que os jovens negros e pobres morrem mais em confronto com a polícia porque eles são mais agenciados pelo tráfico de drogas em tais territórios e porque se envolvem mais com a criminalidade violenta. As explicações falham em considerar a seletividade racial na construção de indivíduos e comunidades puníveis. Uma constatação óbvia é que a polícia faz mais apreensões de drogas nas 
favelas porque tais territórios são os alvos preferenciais das buscas e apreensões. Há que se perguntar, por exemplo, qual seria o resultado e o perfil das vítimas se as intervenções militares ocorressem com a mesma intensidade nas "áreas nobres" da cidade.

No mesmo sentido, é razoável inferir que jovens negros morrem mais em "confronto" com a polícia porque as intervenções militares - e as práticas extrajudiciais - têm os jovens negros como alvospreferenciais. Portanto, as diferentes estratégias de policiamento dependem também da definição mesmo das categorias "crime", "criminoso" e áreas "perigosas". Tais concepções informam não apenas as decisões políticas sobre as geografias sociais a serem preservadas e/ou combatidas, mas também a lógica racial do estado democrático de direitos. Em outras palabras, nas geografías-problema o "arbítrio" policial não representa um desvio anti-democrático porque na verdade o nosso regime racializado de cidadania depende da (e é reproduzido pela) violência policial. A concentração da violência policial, dos padrões de vulnerabilidade social e dos homicídios em bairros predominantemente negros sugere, pois, um padrão mórbido de governança espacial, ou, se o leitor/a preferir, uma necropolitica espacial. Uma agenda de pesquisa politicamente engajada e interessada em desvendar tais padrões poderia começar por analisar os números da atividade policial desagregados por raça e por distritos da cidade de São Paulo, tentar entender a gestão urbano-territorial do medo, sua racialização e seus desdobramentos na disciplina espacial de determinados corpos, na prisão em massa e - quando as tecnologias de disciplinas encontra seus limites - nos massacres policiais de jovens negros do sexo masculino. Neste sentido, mais que hipóteses consolidadas, o presente artigo oferece apenas "pistas" para se desvendar como as diferentes geografias da metrópole (delineadas por raça e classe social) se constituem em locus diferenciados onde padrões de governança espacial assumem formas diversas: proteção para alguns e morte para outros.

\section{CONSIDERAÇÕES FINAIS}

Este artigo procurou delinear, a partir das diferentes manifestações da violência institucional, - da segregação territorial, dos homicídios, da deficiente distribuição da rede hospitalar, da vulnerabilidade social e da violência policial - os constituintes do que chamo de 
necropolítica racial em São Paulo. Não por acaso, a favela aparece como um dos aspectos centrais da economia da violência: ela ambienta suas principais narrativas e é imaginada- constituída em tais encontros letais. O que equivale a dizer que a favela - como uma dimensão do espaço urbano racialmente produzido - é o resultado de processos políticos conscientes, pelos quais o Estado impõe sua estratégia seletiva de contenção social. Propõe- se o conceito de necropolítica espacial como categoria útil para analisar (e lutar contra) a distribuição calculada da morte em determinadas geografias delineadas por raça e classe social. Este pode ser um passo para uma agenda de pesquisa (geográfica) comprometida em desvendar as artimanhas espaciais do racismo e suas consequências letais para os grupos que carregam "o sacrilégio da cor".

\section{REFERÊNCIAS BIBLIOGRÁFICAS}

ADORNO, S. Discriminação Racial e Justiça Criminal em São Paulo. Novos Estudos CEBRAP. Novembro, no. 43, São Paulo, 1995.

AGAMBEN, G. Homo Sacer: Sovereign Power and Bare Life. S. University Press, 1998.

ALASAYYAD, N. e ROY, A. Modernidade Medieval: Cidadania e urbanismo na era global. Novos Estudos Cebrap, 85,pp. 105-28. São Paulo, 2009.

ALVES, Jaime Amparo. (AMPARO-ALVES, Jaime). Necro-política espacial: a produção racial da morte em São Paulo. Revista da ABPN, v. 1, n. 3-nov-fev, p. 89-114, 2010.

BALIBAR. Etienne. Outlines of a Topography of Cruelty: Citizenship and Civility in the Era of Global Violence. Constellations. Volume 8, Issue 1, pages 15-29, March 2001.

BARBOSA, M. I. da S. Racismo e saúde. São Paulo. Tese (Doutorado em Saúde Pública) Faculdade de Saúde Pública, Universidade de São Paulo, 1998.

BATISTA, L. E. Pode o estudo da mortalidade denunciar as desigualdades raciais? In BARBOSA, Maria. L. (org). De preto a afrodescendente. EdUfscar, São Carlos, 2003.

CALDEIRAS, T. City of Walls: Crime, segregation and citizenship in São Paulo. University of California Press, 2000.

CARRIL, L. Quilombo, favela e periferia: a longa busca da cidadania, Tese de doutoramento em geografia, USP, São Paulo, 2003.

CANO, Ignácio. Letalidade da Ação Policial no Rio de Janeiro., ISER, 1997. 
CSDDH. CENTRO SANTO DIAS DE DIREITOS HUMANOS. Mapa da Violencia Policial. Arquidiocese de São Paulo, mimeo, 2009.

COSTA, L. A. M. O ideário urbano paulista na virada do século: O engenheiro Theodoro Sampaio e as questões territoriais e urbanas modernas em São Paulo (1886-1903). São Carlos: RIMA, 2003.

DAVIS, M. Planet of Slums. Nova York, Verso, 2006.

FANON, F. BlackSkin White Mask. New York: Grove Press, 1967.

FERGUSON, J. e GUPTA, A. "Spatializing states: towards an ethnography of neoliberal governmentality". American Ethnologist. Califórnia, 29, pp. 981-1002, 2002.

FLAUZINA, Ana. Corpo negro caido no chao: O sistema penal e o projeto genocida do estado brasileiro. Dissertacao de Mestrado. Universidade de Brasilia, 2008.

FOUCAULT, M. History of Sexuality: an introduction. New York: Vintage Books, 1990.

.Governmentality' (lecture at the Collège de France, 1 February). In: BURCHELL, Gordon, and MILER (ed.). The Foucault Effect - Studies in Governmentality. Chicago: Chicago University Press, (1991[1978]).

The birth of biopolitics. Lectures at the College of France 1978-1979. Palgrame

Macmillan, Hamisphere, 2008.

. "Society must be defended": lectures at the College de France, 1975-76, 1st Picador pbk. edition. New York, Picador, 2003.

FRY, P. Why Brazil Is Different. Times Literary Supplement, December 8:6-7, 1995.

GILMORE, Ruth. Golden Gulag: Prisons, Surplus, Crisis, and Opposition in Globalizing California, University of Californy Press, 2007.

GOTTDIENER, M. The social production of space. University of Texas Press, 1985.

HARVEY, D. "The right to the city", The New Left Review 53, New York, sept/oct 2008.

. Discurso de abertura da tenda de reforma urbana, Forum Social Mundial,

Belem do Para, mimeo, 2009.

HUMAN RIGHTS WATCH. Lethal Force Police Violence and Public Security in Rio de Janeiro and São Paulo. Waghington, 2009.

LEFEBVRE, H. The Production of Space. Oxford: Basil Blackwell, 1991. 
LEMKE, T. The birth of biopolitics: Michael's Foucault's lecture at the College de France on neo-liberal governmentality. Economy and Society, 30, 190-207, 2001.

MARCOS, F. P; MAGGIE, I. Divisões Perigosas: Políticas Raciais no Brasil Contemporâneo.

Rio de Janeiro, Civilização Brasileira, 2007.

MASSEY, D. \& DENTON, N. American Apartheid: Segregation and the Making of the Underclass. Cambridge, MA: Harvard University Press, 1993.

MBEMBE, A. "Necropolitics". Public Culture, Duke, 15(1): pp. 11-40, 2003.

MERRY, S. E. "Spatial governmentality and the new urban social order: controlling gender violence through law", American Anthropologist. New York, 103: pp. 16-29, 2001.

MUNANGA, K. . Rediscutindo a Mestiçagem no Brasil: Identidade Nacional Versus Identidade Negra. Petrópolis, Brazil: Editora Vozes, 1999.

MUSUMECI, Leonarda et. al. Geografia da violencia na região metropolitana do Rio de Janeiro, 2000-2005. Boletim Segurança e Cidadania. Rio de Janeiro, v. 5, n.11, out. 2006.

NAGANGAST, C. Violence, terror and the crisis of the state. Annual Review of Anthropology 23: 109136, 1994.

OLIVEIRA, R. J. Segregação urbana e residencial em São Paulo. Tese de doutorado. PUC-SP, 2008.

OVP - OBSERVATÓRIOS DAS VIOLÊNCIAS POLICIAIS. Disponível em:< http://www.ovp-

sp.org/>. Acesso em: 10 maio 2011

KAMEL, Ali. Não somos racistas: uma reação aos que querem nos transformar numa nação bicolor. Rio de Janeiro: Nova Fronteira, 2006.

PAIXAO, Marcelo. Antropofagia e Racismo. LAESER, 2005. Disponivel em : http://www.laeser.ie.ufrj.br/PT/Documents/Livros/ANTROPOFAGIA\%20E\%20RACISMO.p.

PINHEIRO, P. S. et al. Violência fatal: conflitos policiais em SP (81-89). São Paulo, Revista da USP, no9, p. 95-112, 1991.

REUBEN, Rose-Redwood. "Governmentality, geography, and the geo-coded world", Progress in Human Geography, 30, (4): pp. 469-486, 2006.

ROBINS, S. "At the limits of spatial governmentality: a message from the tip of Africa", Third World Quartely. Cape Town, v23, no 44: pp. 665-689, 2002. 
ROLNIK, R. "Territórios negros nas cidades brasileiras (etnicidade e cidade em São Paulo e no Rio de Janeiro)", Estudos Afro-Asiáticos. Rio de Janeiro, n-17, 1989.

. "Exclusão Territorial e Violência: O Caso de São Paulo". São Paulo Perspectiva, São Paulo, v.

13, n. 4, 1989.

ROMIO, J. Homicídio de mulheres negras na cidade de São Paulo. In: Retratos e Espelhos:

Raça e Etnicidade no Brasil e nos Estados Unidos. FEA/USP, p. 225-248, 2009.

ROSE, Nicolas. Power and Freedom: Reframing Political Thought. Cambridge Univerty Press, 1999.

SAO PAULO. Mapa do Exterminio: execuções extrajudiciais e mortes. São Paulo, 2009. Disponível

<http://www.acatbrasil.org.br/down/DOSSIE_pena\%20de\%20morte\%20final.pdf>. Acesso: 10 maio 2011.

SAO PAULO. Pena de Morte llegal e Extrajudicial. São Paulo, 2005. Disponível em:< http://www.observatoriodeseguranca.org/files/Pena\%20de\%20Morte\%20llegal\%20e\%20Ext ra\%20Judicial\%20-\%20So\%20Paulo\%20-2005.pdf>. Acesso: 10 maio 2011.

SANTOS, M. O espaço do cidadão. Editora da Universidade de São Paulo, 7ạ Edição, São Paulo, 2007.

SANTOS, S. B. As Ongs de Mulheres negras no Brasil. Sociedade e Cultura, vol 12, n.02, 2010.

SEABRA, O.C. São Paulo e os signos da modernidade: a questão da segurança privada. Revista do Departamento de Geografia. São Paulo, n6, 1990, p.92-126.

SECRETARIA DE PLANEJAMENTO (SEMPLA). Dados demográficos municipais. Disponíveis em:< sempla.prefeitura.sp.gov.br/>. Acesso em: 12 março2009

SILVA, J. Violência e Racismo no Rio de Janeiro. EDUFF, Niterói, 1998.

SINHORETTO, J. Os justiceiros e sua justica. Linchamentos, costumes e conflito. São Paulo: IBCCrim, 2002.

SPOSATI, A. de O. Vida urbana e gestão da pobreza São Paulo, SP; Cortez Editora; c1988.

SKIDMORE, T. Racial Ideas and Social Policy in Brazil, 1870-1940. In The Idea of Race in Latin America, 1879-1940, ed. R Graham, pp 7-36. Austin: University of Texas Press, 1990.

TELLES, E. Skin Color and Racial Segregation in Brazil. American Sociological ReviewVol. 57, No. 2 (Apr., 1992), pp. 186-197

VÉRAS, M. P. B. "Novos olhares sobre São Paulo: notas introdutórias sobre territórios, espaços e sujeitos da cidade mundial." Margem. São Paulo, no 6, dezembro, 1997. 
. Trocando Olhares: uma introdução à construção socilógica da cidade. São Paulo,

Studio Nobel/Educ, 2000.

VARGAS, J. C. e ALVES, Jaime Amparo. Geographies of death: an intersectional analysis of police lethality and the racialized regimes of citizenship in São Paulo. Ethnic and Racial Studies, pp.590610, 2009.

VARGAS, J. C.. Apartheid Brasileiro: Raça e Segregação Residencial no Rio de Janeiro. Revista de Antropologia, USP, v.48 (1), 2005.

VILLAÇA, Flávio. Espaço intra-urbano no Brasil. Studio Nobel; São Paulo: FAPESP, 2001.

WACQUANT, Loïc. (2008). As duas faces do gueto. Trad. Paulo Cezar Castanheira. São Paulo: Boitempo.

WAISELFISZ. J. Mapa da Violencia 2011: Os jovens do Brasil. Unesco, Brasilia 2011.

\section{Artigo recebido em 22/08/2011.}

Artigoaceito em 20/11/2011. 